\title{
'Flowing' under the radar in a multifaceted liquid reality: The ekerk narrative
}

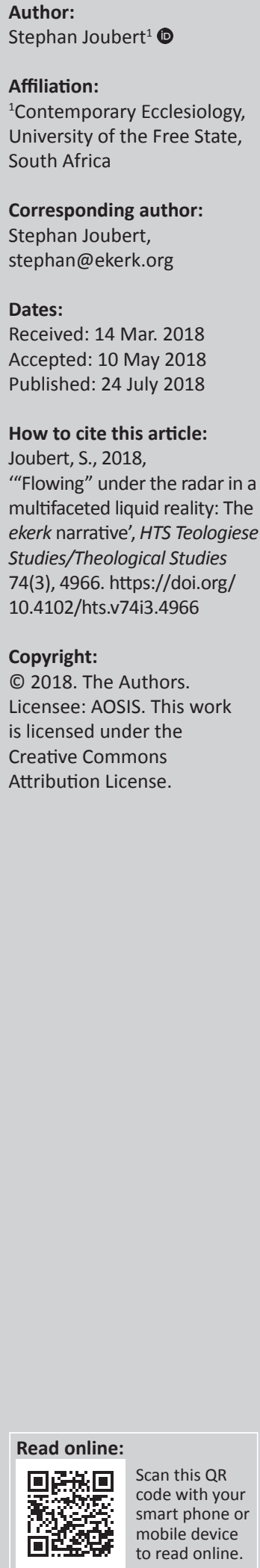

\begin{abstract}
We live in a liquid new world driven by incessant change. Our reality is constantly shaped by new forms of non-linear individualism, which is expressed in countless factions, networks, tribes and alliances. Social systems do not maintain their shape for very long, because they decompose and melt faster than the time it takes to cast them, according to the sociologist Zygmunt Bauman. Religious institutions that do not come to terms with these rapid rates of change soon find themselves trapped in a so-called parallel universe, with hardly any influence on society. In order to embrace our fluid new reality with its numerous open systems and everincreasing levels of complexity, ekerk understands herself as a movement of Jesus followers whose tribal identity is shaped around his teachings on the Kingdom of God, and which is reflected in the values of relationality and generosity. We have 'tribal habitats' in various digital and physical spaces. Under the radar of institutionalised church and academia, but also as their ally in a somewhat subversive manner, ekerk facilitates the spreading of the good news of Jesus in decentralised but very real ways. ekerk also runs a large generosity ministry, as well as various seminars, meetings and growth programmes such as DieGang/TheGang to invest in young Christian leaders.
\end{abstract}

\section{ekerk is ...}

ekerk [echurch] is an independent 'glocal' (i.e. 'global' and 'local') faith movement with an organic presence on social media and elsewhere (cf. Nell 2016). Founded in 2002, ekerk's identity is explicitly anchored in Jesus. In order to communicate his message in palpable, visual and intelligible ways, we have chosen to focus on the prominence of God's upside-down kingdom in his teachings. Together with a large digital footprint (for instance, over 2.5 million annual emails are sent out to members), ekerk hosts learning communities in various formats at different venues across South Africa and internationally, as well as local weekly gatherings. Research reports on contemporary trends and issues are published regularly on the ekerk website and application. ekerk also runs consecutive 18-month entrepreneurial leadership programmes for younger church leaders (DieGang/TheGang), while sustaining a large ministry of generosity across South Africa.

ekerk plays alongside formal church and academia, while simultaneously serving these and other institutions in somewhat subversive ways. Although ekerk has developed the ability to constantly 'morph' in ever-changing landscapes, the fact that this movement retains its momentum and maintains its flow is a result of what Zygmunt Bauman (2012) describes as:

... the prolonged time of 'interregnum' - when the old ways of doing things no longer work, the old learned or inherited modes of life are no longer suitable for the current conditio humana, but when the new ways of tackling challenges and new modes of life better suited to the new conditions have not as yet been invented, put in place and set in operation ... (p. 1)

\section{Reality turned liquid ... and non-linears started thriving!}

Over the past two decades, South Africa has experienced seismic and systemic shifts from apartheid to post-apartheid, colonialism to post-colonialism, modernism to post-modernism, Christendom to post-Christendom and currently from non-liquid modernity to liquid modernity. Bauman (2011) describes 'liquid modernity' as:

\footnotetext{
.. the currently existing shape of the modern condition, described by other authors as 'postmodernity,' 'late modernity,' 'second' or 'hyper' modernity. What makes modernity 'liquid', and thus justifies the choice of name, is its self-propelling, self-intensifying, compulsive and obsessive 'modernization', as a result of which, like liquid, none of the consecutive forms of social life is able to maintain its shape for long. ${ }^{1}$ (p. 8)
}

1.In this regard, Carlo Bordoni (2016) prefers the concept interregnum as such to describe our present time of instability and all the socia degradation it entails, as one that has actually extended beyond liquid modernity. 
Globalisation and individualisation have caught up with us all, turning our previously solid global village into a liquid matrix of random connections and disconnections with an infinite volume of permutations.

According to Bauman (2007:1; 2012:4-5), the short life expectation of the vast majority of contemporary social forms or structures that previously provided the cement for our respective cultures, as well as the ensuing fragmentation of social bonds, forced us into this new era of liquid modernity. In this instance, change is the only permanence, and uncertainty the only certainty. The collapse of long-term thinking, planning and acting, coupled with the weakening of the social structures where such activities took place previously, also creates new forms of non-linear individualism, which is expressed in countless factions, networks, tribes and alliances.

In fluid modernity social systems do not maintain their shape for very long, because '... they decompose and melt faster than the time it takes to cast them' (Bauman 2007:1). Therefore, it is not helpful to view fluid societies in terms of social structures, that is, as 'solid totalities', but rather as networks with '... a matrix of random connections and disconnections and of an essentially finite volume of possible permutations' (Bauman 2007:3). Within this uncertain world of incessant change, where today's successes will count for nothing tomorrow, and where numerous sections of humanity are still excluded from the realms of economic participation and moral obligation, consumerism, according to Bauman (2010:57), is one of the few remaining social skills for individuals. Consumer choice is probably even the new 'meta-value' of this liquid world, with its digital and literal mega-malls:

Society is seen less and less as a product of shared labour and common values and far more merely as a container of goods and services to be grabbed by competing individual hands. (Davis 2016:3)

It appears that non-linear individuals thrive in this uncertain age of liquid modernity. Lash aptly describes such individuals as 'combinards', because of their constant forging of networks and alliances (cf. Joubert 2013:115). Order, predictability and stability are not integral to their understanding of reality. Non-linears intuitively sense that one of the rudimentary characteristics of fluid modernity is that causes and effects are not linked, that the whole is simply not the sum of the parts and that related processes do not steer systems to distinct and inevitable ends (cf. also Geyer 2003:4-5). They know that they are forced to live in an atmosphere of risk in which life changes and knowledge are precarious, because of the incessant rate of change and a new view of life as a series of (dis)connected episodic moments. Non-linears are also the first to embrace new communication technologies in order to circumvent the time-consuming and possibly also emotionally taxing business of facing other individuals in their physical proximity. 'Online life' has become part and parcel of liquid modernity, one where people prefer their multifarious screens to dominate their lifeworlds, because they have allowed digital reality to infiltrate and control all facets of their lives. Hence, Bauman's concern that the evergrowing absence of meaningful face-to-face relationships, which is fundamental 'to an ethical life lived in the company of others' (Davis 2016:4), presents a huge problem that is unique to our age and time.

Globally, non-linears and others are fast giving up on formal religious institutions with their solidified structures, set dogmas and fixed rituals, as well as on other previously trusted institutions such as the state, ethnic groups, nuclear family and so on. ${ }^{2}$ Without recourse to set ethical principles and rules, many people find themselves trapped in a liquid world of great moral uncertainty. However, this could potentially be of benefit, because '... uncertainty is the home ground of the moral person and the only soil in which morality can sprout and flourish' (Davis 2016:9-10). In Bauman's view, liquid modernity at least creates the opportunity that life's uncertainties will stir people's anxiety in such ways as to allow for new moral choices. However, at the same time, the danger is inherent that, instead of opting for moral choices, people will yet again seek '... evermore ingenious ways of deferring to abstract rules and new forms of authority' (Davis 2016:10; cf. also Bauman 1999). The challenge for any Jesus movement that aspires to have an impact within fluid modernity is to take the risk of standing in this 'morally neutral' gap. It is ekerk's challenge amid linears, non-linears, pre- and post-modernists, believers and non-believers to shine the light on Jesus in fresh, metanoetic ways. Metanoia for us means:

... the urgent boundary-crossing call and magnetic invitation of Jesus (Matt 4:17) to a new life of resilient followership and relentless love for God and his handworks ... Metanoia is an ongoing process of metamorphosis. It is an incessant longing for, as well as a shared participation in the 'relationality' of God, since metanoia also equals agape or unconditional love for Him and others. (Joubert 2013:122)

\section{Ever-present realities: Solid church and solidified theology}

The liquefying of a once-fixed society, which consisted of a bound set of predictable structures, institutions, norms and values, is one of the defining characteristics of the present South African landscape. In this instance, the ambivalent and radically contingent nature of fluid new personal and social identities is reflected in those ever-changing shapes of contemporary organisational life (cf. also Elliott 2007:8). Although religion is not exempt from such changes, the South African context has, over many years, also spawned a form of 'solid church' that has effectively solidified modernism's fixed ideological norms, rules, as well as class-oriented affinities and identities. As a result, it is not very responsive to the increasingly fluid dimensions of our culture. Solid church is characterised by a blind faith in official religious dogmas,

2 Kobus Schoeman's (2014) study on the present state of Afrikaans mainline churches found that, between 1990 and 2010, the Hervormde Kerk membership declined from 192541 to 105 000; the Gereformeerde Kerk membership declined from 78945 to 63 951, and the Nederduitse Gereformeerde Kerk membership declined 78945 to 63951 , and the Nede
from 1340065 to 1089055 . 
strict adherence to predetermined truths, a mindset of rigid theological classification, as well as centralised socio-religious control. In such reductionist religious environments, various synods, religious head offices and church boards consider it their duty to define, defend and implement prescribed beliefs and behaviour 'from the top'. According to Peter Ward, solid church has generally mutated from its original basis '... into communities of heritage (that embody the inherited tradition), communities of refuge (a safe place from the world), and communities of nostalgia (living in past successes)' (Hirsch 2007:197). It is not surprising that such churches have seriously decreased their ability to engage in the mission of Jesus. The original gospel code has been mutated in their midst, because they have chosen to be less adaptable to cultural changes in favour of entrenching their traditional roles as gatekeepers of the fast-shrinking religious status quo. However, in any liquid society where social control has been commodified and privatised (cf. Blackshaw 2005:32), such rigid efforts to maintain religious stability and order, while also trying to impose fixed ideas indiscriminately on the rest of society, are frowned upon and only assist in the increased exodus from organised religion.

Christianity has not lost its lure, but solid church, as its official custodian, has lost much of its influence. It has turned into an inherently consumptive system where 'active' congregation members are, in fact, passive most of the time, because they are mostly in the receptive mode when they show up at comfortable church venues, in order 'to get fed spiritually'. The biggest threat facing vibrant expressions of church in liquid modernity is not theological liberalism but consumerist religion. This simple truth that we cannot be relevant followers of Jesus by trying to consume our way into discipleship has given birth to ekerk and has remained our challenge ever since. Solid church is blind to the changes that are dragging us all into the future. Therefore, it is losing its influence as an agent of change and grace in the world. Sadly, more companies currently want to change the world more than the church, according to Len Sweet (2009).

Another equally exciting challenge for us at ekerk is to avoid the entrapments of a so-called solid theology. In many academic circles, where theology has become an end in itself, the number of publications, positive peer reviews and the recognition of like-minded theologians are all that matter. ${ }^{3}$ While N. T. Wright (2013) laments such scholars' left-brained efforts to turn theology into mathematics, solid theology has also turned the Bible into a dead book about yesterday's heroes, on which they continue to perform post mortems - that is, if they have not already given it a decent burial as a politically incorrect document. Solid theology fails to

3.Zygmunt Bauman (quoted in Davis 2016:5, footnote 1) laments the peer review system deeply engrained in academia: 'I suspect that the peer review system carries system deeply the blame for the fact that something like $60 \%$ or more of journals a good part of the blame for the fact that something like $60 \%$ or more of journals articles are never quoted ... and (in my reception at any rate) that 'learned journals' (with a few miraculous exceptions) ooze monumental boredom. To find a new and enlightening and inspiring idea ... browsing through thousands of journal pages is a too often called for. With my tongue in cheek only, I'd suggest that were our palaeolithic ancestors to discover the peer-review dredger, we would still be sitting in caves. embrace any form of missional theological reflection. Only when mission accompanies theology:

... when it defines the way theology works, then it becomes the task of such missional theology to accompany and support the church in its witness by testing all that the church says and does in terms of its calling to be Christ's witness. (Guder 2015:13)

\section{Forging a new tribe of Jesus followers}

The pillars of reductionism, order and predictability, on which solid theology and solid church firmly rest, do not offer much support to narrow down the ever-widening gap between church and society. ekerk is intentionally positioned in this gap with the challenge to practise an embodied theology that is relevant not only in cyberspace but also in marketplaces, coffee shops, squatter camps, theological discussion groups, local churches and so on. One of our provocative experiments in this regard is a leadership programme called DieGang/TheGang, which has been in place for the past 4 years. Between 13 and 18 younger church leaders at a time from various denominational and racial backgrounds are invited to embark on an 18-month adventure. The aim is not only to learn from but also to reteach these mostly non-linear leaders how to cross more efficiently between fixed and fluid cultures, as well as to embrace a relational, vibrant theology. During this journey, five specific experiences introduce them to semiotic theology via an advance with Leonard Sweet; how to follow in the footsteps of Jesus (via a weeklong experiential trek through Galilee and Judea); how to engage in a serious reality check (by staying over in Tembisa with Roedolf Botha); an exercise in embodied spiritual formation (with Tom Smith in the Drakensberg); and participatory exercises in intuitive leadership in the Bushveld. In between these events, and with the aid of academic books, Skype discussions and frequent personal contacts, DieGang/ The Gang grows into a community of friends who interactively reflect on new ways of truly following Jesus.

ekerk also hosts learning communities across local churches in South Africa and abroad. During such day seminars, which have been attended by close to two thousand people over the past 2 years, we introduce church leaders and others to various facets of liquid modernity through ekerk's research reports (regularly published on our website), as well as to new academic research in various fields. We are very intentional about equipping people to be good semioticians (that is, effective context readers), committed disciples of Jesus and servants of others wherever they live, work, play, operate or travel. In the words of C. S. Lewis (2001), we want to be a good infection. We want to facilitate the growth of 'metanoetic' communities of individuals everywhere to assist in the organic growth of the kingdom of God and his church. It is all about 'reciprocal conception', or as Bauman (2001:xiii) puts it: '... it is about society shaping the individuality of its members and the individuals forming society out of their life actions'.4

4. New church plants, or separate communities of faith and theological semina............. not on our radar screen. From our perspective, such endeavours would be an epistemic, 'solid ecclesiology-driven', misunderstanding of the nature of fluid epistemic, 'solid ecclesiology-driven', misunderstanding of the nature of fluid
modernity, where such fixed structures and institutions dissolve faster than the time modernity, where such fixed structures and institutions
it takes to build them, as Bauman has reminded us! 
Obviously, this entails a kingdom-of-God mindset, coupled with a new tribal identity.

The idea of the tribe is organic, as Miriam Cooke (2014:56) aptly reminds us: 'Over time tribes and their clans may amalgamate or form new tribes ...'. Indeed! The terms 'networked individualism' or 'hyper-individualism' are frequently used nowadays to describe the nature of digital subjectivity. The Italian theorist Michel Maffesoli is perhaps more correct that this is not so much a world of hyperindividualism sold out to the illusion of connection but rather a global culture based on new tribalism (cf. Kroker \& Kroker 2013:4). Tribal networks thrive in the post-solid world of digitalised social media, one which '... complements, rather than replaces traditional communities: e-citizenship has both a local and a global dimension' (Sanz \& Romero 2007:5).

In liquid modernity, non-linear individuals, with their evershifting identities, more than ever need tribal spaces where they can belong. Not only they, but also individuals and groups who experience various forms of alienation in this fast-changing liquefied landscape, as well as high learners, curious church members, leaders and numerous others, are seeking morally grounded places to connect with Jesus and others. Previously, when geography used to be important, such tribes had to be local and rather one-dimensional in terms of identity, but now that the Internet has eliminated geography (cf. Godin 2011) there are tribes everywhere, as well as groups of individuals that simultaneously belong to such groups and to official religious institutions. However, being part of a tribe is not the point; it is about being part of a tribe that has become a movement of Jesus followers where people are energised, transformed, connected, leveraged and equipped to embody the right type of impact in their respective realities. This is ekerk's aim.

As personal and social identities continue to grow, merge and evolve at ever-increasing rates in liquid modernity, we at ekerk face the daunting challenge of constantly recalibrating ourselves. In order to remain a tribal movement, we have to embrace new understandings of personal and social identity, new language, new technologies, new conceptualisations of reality and new ecclesiologies, without ever sacrificing our core connection to Jesus. In our efforts to incorporate the core ingredients of his teachings in relevant expressions of relational discipleship, we have learned, and continue to learn, that God's love is expressed in koinonia and selfless service to others. This red-hot message of Jesus, à la Ernst Käsemann (cf. Joubert 2017:289, footnote 61), forced us out of our solid church comfort zone, where fixed budgets normally determine the nature and scope of generosity. ekerk's board of directors challenged our team from early on to give away $50 \%$ of ekerk's income annually. ekerk's master narratives in this regard are the story of John the Baptist in Luke 3:1-20, who challenged even the poorest of the poor to share one set of garments, if they possess two sets, and that of Zacchaeus in Luke 19:1-10, who, after Jesus entered his home, ${ }^{5}$ decided

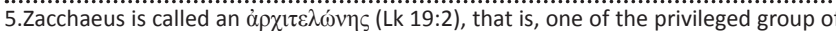
chief tax collectors who had sufficient funds to pay the provincial taxes, due to the Romans, in advance. He would have been a multi-millionaire in today's terms. to henceforth give away half of his possessions to the poor. Our long-term financial involvement in, among others, an old-age home, two children's homes, imaginative ministries such as PEN, Echo and Word for Word have taught us a great deal about relational generosity. An imaginative 'Build-aHouse-a-Month' project, which we ran in local townships for 2 years, brought us into contact with many new, and now beloved, faces on the South African landscape. Everywhere, the recipients of our generosity turned into our new mentors and teachers.

\section{Yet another seismic shift: Digital reality as an integral part of liquid modernity}

Reality is no longer only a physical space. Geographical and political divisions do not have the final say. Non-geographical cyber reality now sets the pace (and the tone!), because digital technologies have succeeded in putting the entire world in touch with each other 24/7. Our new technologically constructed reality has effectively removed all physical (and hierarchical?) distance between people. Everyone 'can communicate rapidly and be non-presentially, liberated from the restrictions of time and space' (Sanz \& Romero 2007:4). The globalisation of knowledge is also an ever-present reality, as well as a new understanding of time. Together with linear time's fixed forward march of seconds, minutes, hours, days and years, cyberspace confronts us with numerous new temporal realities such as asynchronous time, accelerated time, ephemeral time and frozen time that constantly intersect with real-world time. Cyberspace has indeed become the new social frontier, where cross-cultural contact and communication, together with new sedentary, yet nomadic, digitalised identities are the order of the day. South Africa is not exempt from all these changes. According to a News24 report, ${ }^{6}$ nearly everyone in South Africa is online nowadays. According to a study by Qwerty on digital growth in South Africa, ${ }^{7} 28.6$ million people, or $52 \%$ of the South African population, use the Internet regularly. They do this mostly on their mobile phones (which comprises $78 \%$ of locally generated web traffic). Locals also spend a staggering $70 \%$ of their weekly activities on social media platforms alone: Facebook (49\%) is just ahead of YouTube (47\%), WhatsApp (45\%) and FB Messenger (31\%). The 18-24 and 25-34 age groups are the largest social media groups, with a huge rise in the 45-65 + group, probably because of their higher disposable income.

Nobody has prepared us for the huge ideological shifts and endless paradoxes of the digital era. Over the past few years, digital processes have had an unprecedented impact on every possible profession, from medical science to architecture, or from agriculture to second-hand car sales. In this new era of 3D printing, participatory design and digitalised surgery, where traditional boundaries are porous

6.https://www.news24.com/PartnerContent/a-digital-era-the-south-africanstatistics-20170425

7.http://qwertydigital.co.za/wp-content/uploads/2017/08/Digital-Statistics-inSouth-Africa-2017-Report.pdf 
and blurred, and where physical and digital tools are used interchangeably (cf. Picon 2017), new conceptualisations of reality take shape constantly. In turn, they shape all of us. Gackenbach and Bown (2017) rightly state:

As technology has aided humans to transcend the limit of their physical bodies, the Internet, digital media, and VR technologies are already chipping away at the illusions of individuality and the self. (p. xxiv)

Interactive digital-media experiences provide (unique) interfaces between our biological selves and our digital selves, bringing our concepts of self and personality into turmoil. Digital identity dimensions are even influenced by the very software tools for self-presentation in online environments (such as avatars, passwords, usernames, digital personas and selfies as visual rather than verbal forms of self-expression):

Technology has become a sort of infrastructure of human life itself, a medium of human life. What it is to travel in our contemporary lifeworld, what communication is, what work is, what perception is, can no longer be determined independently of technical structures. (Böhme 2012:18)

The social norms of any online community might encourage individuals:

... to portray themselves in a way that accurately reflects their real-world selves, as in traditional social media like Facebook. The norms might encourage them to adopt imaginary identities, as in games. Or the norms might create an identity dimension that mixes reality and fantasy. (Suler 2017:3)

The advantages of new forms of interaction on digital platforms in terms of knowledge acquisition, community growth and healthy interpersonal contact, but also the dangers of individualised self-expression that has become dependent on 'buttonised likes' and the constant need for affirmation from online audiences, are ever-present realities. ${ }^{8}$

Religion is also big on the Internet. Between 1991 and 2005, the number of Christian webpages increased from 610470 sites to over 9 million, an increase of almost $1.400 \%$. Studies by PEW show that, only in the US nearly 82 million people:

... seek religious information, read religious news or current affairs, exchange emails with religious or spiritual content, respond to religious charities or requests, participate in online religious discussion or blogs, or engage in online activity for evangelisation, faith education or ministry training. (StuartButtle 2013:12)

We cannot ignore, nor escape, the impact of globally adopted communication technologies on the development of personal and social identities and behaviour. The days of unmediated, technology-free identity formation or social interactions are over, because all of reality now plays out on a continuum between virtual and real spaces. Both digital and non-digital subjectivities, with their often contradictory values, define us

8.Nowadays, a new brand of cyber-psychologists have to address the problematic by-products of our technological age in areas such as gaming, cybersex, online shopping and social media attraction (cf. Suler 2017:3). (at least we all walk around with mini-computers in our pockets called 'cell phones', which filter half of our conversations and relationships!). Digital technology no longer simply represents the real world out there; it has become an emergent reality principle in its own right, '... driving culture and society forward by ever proliferating digital innovations and, at the same time, providing compelling new ways of thinking about the digital reality which surrounds us' (Kroker \& Kroker 2013:13).

\section{It is all about digital depth, not digital breadth}

In addition to our struggle to find a suitable vocabulary for our digital endeavours at ekerk, we constantly have to remind ourselves of the overlapping yet distinctive identity-shaping dimensions of our online and offline presence. ${ }^{9}$ Over the past few years, we have intentionally chosen to pursue less robust routes by moving away from highly interactive Internet platforms in particular. Some of the very first digital churches explored interactive, avatar-driven, routes - for example, Church of Fools, which later merged and morphed into St. Pixels, was considerably popular initially, but soon 'novelty fatigue' set in, as it turned into a platform for disillusioned church expats and angry atheists to vent their opinions in fierce online debates and trite discussions. ${ }^{10}$ This sensitised us to the presence of online trolls and other unsavoury digital personas that also began to frequent ekerk's interactive digital spaces. ${ }^{11}$ The millennials on our team soon opted to recalibrate our Internet platform, fearing that ekerk's identity would be jeopardised if we allowed people unlimited interactive access to our website. In response, we have chosen a more expressive mode, as Suler (2016) describes it. ${ }^{12}$ FB Messenger and email are currently our preferred routes to facilitate interpersonal interactions and to address the immense load of personal questions or spiritual problems.

It is a known fact that people make concise decisions to digitally connect with others who share similar beliefs, values and interests - hence our tribal route, as well as the development of user-friendly spaces. We have also learned the hard way that digital longevity is dependent on a clear identity, trustworthiness, integrity and solid content that is packaged in chunky bites of no longer than 300-400 words, when text is the main form of communication, or by means of

9.On the one hand, there is the danger that personal identities could become compromised 'when people strive to maintain an ongoing symbiotic connection to others online in order to receive constant acknowledgment of their thoughts and feelings' (Suler 2017:3). On the other hand, deeply shared interests or beliefs could feelings' (Suler 2017:3). On the other hand, deeply shared interests or beliefs could
easily evaporate in this instance in terms of transference between digital and other spaces.

10.Cf. Nell (2016) and Campbell (2005:61-69), who understands online Christianity in terms of the three dominant types, namely cyber-churches, e-vangelism and Christian online communities.

11.According to Fichmann and Sanfilippo (2016:6), online trolling is 'a repetitive, disruptive online deviant behaviour by an individual toward other individuals and groups'.

12.We send out two weekly email messages with the focus on spiritual growth to a large group of inscribed members, coupled with different newsletters every fortnight tailored for specific groups such as leaders or millennials. We produce short video clips ('360 second truths', online Bible schools, etc.), as well as online programmes on spiritual formation for which people need to enrol. Online
prate seminars on various Bible topics are also very popular. 
one or two images, when the Instagram or Facebook routes are followed. In 2017, ekerk has managed to keep visitors to our webpage on average for $2.35 \mathrm{~min}$, and for $1.29 \mathrm{~min}$ per page view. The lesson learned: the amount of traffic on social media platforms is less important than the depth of engagement when longevity is at stake.

In addition to deepening our digital presence, we work hard at being sensitive to our own digital footprint, as well as in assisting others in the maintenance of moral online autobiographies. According to Lyseggen (2017), everyone leaves online breadcrumbs in this fast, multiple, mediated, networked digital world. It might be more than breadcrumbs, though. In a world jettisoned from electronic media to technoculture that is moving at the speed of light, we all have acquired technological autobiographies, whether we know it or not. And no, it is not simply about leaving behind cookies on every website we visit.

From the moment of our medically enabled birth to our inevitable death in increasingly high-tech intensive care units, from a lifetime of computer-assisted education to digitally enhanced workplace experience, from the mass data archives that literally 'bank' human memory to the screens and spools and keystrokes composing the materiality of the regime of computation, the question of individual autobiography has become deeply entangled with the 'companion species' of technology. (Kroker \& Kroker 2013:11)

Even outside of our normal awareness, aspects such as our conjectures, gestures or the ways in which we communicate and relate with each other are being influenced by so-called machine-to-machine data flows within which we circulate '... and on account of which our lives are often enhanced, but sometimes disabled' (Kroker \& Kroker 2013:11). In this world where it is easy to drown in never-ending volumes of data, ${ }^{13}$ we constantly need be sensitive to the type of digital environments we visit or inhabit, as well as to the effects of technology on our online presence (such as prompting us with notifications and suggestions, which, in turn, are based on technology's ability to recognise people's preferences in terms of their digital footprint). Amid numerous new 'freedoms' on offer, a digital Tower of Babel is also being built in our midst.

\section{Sacred digitality, sacred reality!}

The Internet has changed the shape of the church everywhere. An 'electronic reformation' has taken place, one where online faith is no longer a novelty; it is a normal part of liquid modernity. Numerous new opportunities and exciting learning curves face us as followers of Jesus, such as grappling with new perceptions of identity and authority, infinite streams of information, 24/7 contact with the rest of the world and innumerable fusions between ever-expanding physical and digital realities. In order not to fall victim to the age-old problem of solid church, namely to bark at everything

13.Already in June 2015,8796 photos were shared on Snapchat every second, with 58 million photos added to Instagram and 350 million photos to Facebook on a daily
basis. In fact, in 2015, 3.25 billion digital images were uploaded on the Internet basis. In fact, in 2015, 3.25
daily (cf. Lyseggen 2017). they do not understand, followers of Jesus need to be sensitised to the nature of their presence. The digital side of mixed reality should not be viewed only as spaces or places to visit when information is needed or when individuals, ministries or churches want to share their views by means of 'cyberspace monologues'. It should rather be regarded as part and parcel of our new habitat:

Online Christianity is about more than simply utilizing a new medium for proclamation. It is about reshaping ideas of faith and facilitating new ways of gathering as a new 'digital body of Christ' worldwide. (Campbell 2005:61)

Therefore, it is important to constantly shift between 'online religion' and 'religion online', one which also has an offline footprint. While religion online is mainly about '... the provisions of information about and/or services related to various religious groups and traditions ..., online religion, on the other hand, invites Internet visitors to participate in religious practices' (Dawson \& Cowan 2004:7). ${ }^{14}$

Cell phones, tablets and computers have opened up exciting new spaces for spiritual connection and expression. Cyberspace is also sacred space now, hence our passion at ekerk to broaden many believers' dated perception of the Internet mainly as a tool for information. Following Campbell (2005:55), we believe that 'cyberspace provides a viable way to reintroduce the spiritual world into the postmodern context'. We want people to understand their online activities, from Facebook to Instagram, LinkedIn or Twitter, as an integral part of their spiritual life. Our aim is not simply to get more visitors, followers, likes or shares on ekerk's various digital platforms but to facilitate a more holistic spirituality, one that does not divide people's religious online presence from other forms of presence here or elsewhere. Perhaps Chama (1996) captures the ideals of ekerk best:

For many signing in on the Internet is a transformative act. In their eyes the web is more than just a global tapestry of personal computers. It is a vast cathedral of the mind, a place where ideas about God and religion can resonate, where faith can be shaped and defined by a collective spirit. (p. 67)

It is difficult to find some kind of imaginative vocabulary to articulate ekerk's under-the-radar presence and role in this new mixed reality, which blurs the boundaries between so many facets of our lives and which also melts down the religious structures we erect faster than the time it took to build them. We are well aware of the fact that digital devices, as well as the spaces they allow us entry into, are not simply extensions of the 'real world'. At the same time, however, we do not want to create a digitally driven religious ghetto, or a high-speed 'Christianised, Google-like platform', where questions could be answered and problems solved at cyber speed. Online community is never a replacement for the physical community of believers, thus ekerk's continued involvement with local

14.According to Stuart-Buttle (2013), religion online: 'emerges from traditional or official sources set up by mainstream parishes, congreations, religious institutions official sources set up by mainstream parishes, congregations, religious institution or agencies ... which use their online activit. in contrast, online religion relates to unofficial religious participation or activity in popular or self-acclaimed websites, including those of new and alternatives religious movements' (p. 13) 
churches and academic places of learning. It is no longer an either/or but a both/and. In this era of liquid modernity, we have to embrace the fact that our most recent ecclesiologies, as expressions of our embeddedness in contemporary culture, are conditioned, contingent and liquid (cf. Ward 2017:21). They will evolve, grow or even shrink as we continue to make sense of a world where theology will probably entail more than simply faith-seeking understanding, as Anselm of Canterbury famously said many moons ago. Perhaps theology must now also explicitly include notions of 'faith-seeking experience' or 'faith-seeking community'.

In our 'dangerously fluid world' (Sweet 2012:43), religion is not merely 'becoming liquid', as Kees de Groot (2018:2-3) states. Neither is church only now 'moving from the 'solid' phase of a modern institution to the liquid phase of late modern de-institutionalized forms', as he thinks in the same breath. Church is there already. Liquid church is not about institution but about networks of relationships. It is not about religious communities hiding in safe bunkers far removed from reality but about followers of Jesus filling the ethical vacuum created by liquid modernity by embodying his teachings in relevant ways. As Sweet (2008) explains, the goal in the church nowadays must go beyond surviving to thriving in this new culture. We must provide Jesus' message in forms and languages with which people in the current liquid world can resonate. In this instance, ekerk's continued search for valid expressions of the timeless message of Jesus takes place. Amid fluid contexts we want to be in the flow of the gospel. Following Mihaly Csíkszentmihályi's research on flow states (as a reference to a person's complete absorption with an activity at hand ${ }^{15}$ ), we want to be so fully immersed in the message of Jesus that temporal concerns are of less importance. We believe that this is precisely what happens '... when metanoetic people are en route in God's kingdom. They flow. They sacrifice. They endure. They commit. They distribute water in deserts and desolate places in their flow states of commitment, passion and empathy' (Joubert 2013:129).

\section{Acknowledgements Competing interests}

The author declares that he or she has no financial or personal relationships which may have inappropriately influenced him or her in writing this article.

\section{References}

Bauman, Z., 1999, In search of politics, Polity, Cambridge.

Bauman, Z., 2001, The individualised society, Polity, Cambridge.

Bauman, Z., 2007, Liquid times: Living in an age of uncertainty, Polity, Cambridge.

Bauman, Z., 2010, Living on borrowed time: Conversations with Citali Rovirosa Madrazo, Polity, Cambridge.

15. As a result of a flow state: 'the person in flow not only forgets his or her problems, but loses temporarily the awareness of self that in normal life often intrudes in consciousness, and causes psychic energy to be diverted from what needs to be consciousness, and causes psychic
done' (Csíkszentmihályi 1988:33).
Bauman, Z., 2011, Culture in a liquid modern world, Polity, Cambridge.

Bauman, Z., 2012, Liquid modernity, Polity, Cambridge.

Blackshaw, T., 2005, Zygmunt Bauman, Routledge, London.

Böhme, G., 2012, Invasive technification: Critical essays in the philosophy of technology (C. Shingleton, transl.), Bloomsbury, London.

Bordoni, C., 2016, Interregnum: Beyond liquid modernity, Transcript Verlag, Bielefeld.

Campbell, H. 2005, Exploring religious community online: We are one in the network, Peter Lang, New York.

Chama, J., 1996, Finding God on the web, Time Magazine, 16 December, pp. 66-69.

Cooke, M., 2014, Tribal modern: Branding new nations in the Arab Gulf, University of California Press, Berkeley, CA.

Csíkszentmihályi, M., 1988, 'The flow experience and its significance for human psychology', in M. Csíkszentmihályi \& I.S. Csíkszentmihályi (eds.), Optimal experience: Psychological studies of flow in consciousness, pp. 15-35, Cambridge University Press, Cambridge.

Davis, M., 2016, 'Liquid sociology - What for?', in M. Davis (ed.), Liquid sociology; Metaphor in Zygmunt Bauman's analysis of modernity, pp. 1-12, Ashgate, Farnham.

Dawson, L.L. \& Cowan, D.E. (eds.), 2004, Religion online: Finding faith on the internet, Routledge, London.

De Groot, K., 2018, The liquidation of the church, Routledge, London.

Elliott, A. (ed.), 2007, The contemporary Bauman, Routledge, London.

Fichman, P. \& Sanfilippo, M.R., 2016, Online trolling and its perpetrators: Under the cyberbridge, Rowman \& Littlefield, London.

Gackenbach, J. \& Bown, J., 2017, 'Introduction', in J. Gackenbach \& J. Bown (eds.), Boundaries of self and reality online: Implications of digitally constructed realities, pp. xxiii-xxvi, Elsevier Academic Press, London.

Geyer, R., 2003, 'Europeanisation complexity, and the British welfare state', Paper presented to the UACES/ESRC study group on the Europeanisation of British politics and policy-making, Department of Politics, University of Sheffield, 19th September.

Godin, S., 2011, Tribes: We need you to lead us, Piatkus, London.

Guder, D.L., 2015. Called to witness, Doing missional theology, Eerdmans, Grand Rapids, MI.

Hirsch, A., 2007, The forgotten ways: Reactivating the missional church, Brazos, Grand Rapids, MI.

Joubert, S.J., 2013, 'Not by order, nor by dialogue: The metanoetic presence of the Kingdom of God in a fluid world', Acta Theologica 33(1), 114-134.

Joubert, S.J., 2017, 'The kenotic $\mu$ opфn' of Christ and character formation in Paul's ethical discourse in Philippians 2:5-11', in R. Zimmermann \& S. Joubert (eds.), Biblical ethics and application: Purview, validity and relevance of Biblical texts in ethical discourse, pp. 275-290, Mohr Siebeck, Tübingen.

Kroker, A. \& Kroker, M., 2013, Critical digital studies: A reader, 2nd edn., University of Toronto Press, Toronto.

Lewis, C.S., 2001 (1952), Mere Christianity: A revised and amplified edition, with a new introduction, Harper, San Francisco, CA.

Lyseggen, J., 2017, Insight: Navigating in a world drowning in data, Penguin, London.

Nell, I., 2016, 'Virtual leadership?' The echurch as a South African case in point', HTS Teologiese Studies/Theological Studies 72(2), a3570. https://doi.org/10.4102/hts. v72i2.3570

Picon, A., 2017, Urban sensing: Toward a new form of collective consciousness', in K. De Rycke, C. Gengnagel, O. Baverel, J. Burry, C. Mueller, M.M. Nguyen, P. Rahm \& R. Thomsen (eds.), Humanizing digital reality: Design modelling symposium, Paris 2017, pp. 63-72, Springer Nature, Singapore.

Sanz, A. \& Romero, D. (eds.), 2007, Literatures in the digital era: Theory and praxis, Cambridge Scholars Publishing, Newcastle.

Schoeman, W.J., 2014, 'Agter die syfers is gelowiges, gemeeentes en die kerk: ' $n$ Prakties teologiese refleksie oor lidmaatskap', HTS Teologiese Studies/Theological Studies 70(1), Art. \#2677, 10 pages. https://doi.org/10.4102/hts.v70i.2677

Stuart-Buttle, R., 2013, Virtual theology: Faith and adult education, an interruptive pedagogy, Cambridge Scholars Publishing, Newcastle.

Suler, J., 2016, Psychology of the digital age: Humans become eclectic, Cambridge University Press, Cambridge.

Suler, J., 2017, 'The dimensions of cyberpsychology architecture', in J. Gackenbach \& J. Bown (eds.), Boundaries of self and reality online: Implications of digitally constructed realities, pp. 1-26, Elsevier Academic Press, London.

Sweet, L., 2008, AquaChurch 2.0, David C. Cook, Colorado Springs, CO.

Sweet, L., 2009, The dawn mistaken for dusk: If God so loved the world, why can't we? Zondervan, Grand Rapids, MI.

Sweet, L., 2012, Viral: How social networking is poised to ignite revival, Waterbrook Press, Colorado Springs, $\mathrm{CO}$

Ward, P., 2017, Liquid ecclesiology: The Gospel and the Church, Brill, Leiden.

Wright, N.T., 2013, Pauline perspectives: Essays on Paul, 1978-2013, Fortress Press, Augsburg. 